\title{
Multiple Actions of Curcumin Including Anticancer, Anti-Inflammatory, Antimicrobial and Enhancement via Cyclodextrin
}

\author{
Aaron J. Smith*, John Oertle, Dino Prato \\ Envita, Scottsdale, USA \\ Email: * Aaron@envita.com
}

Received 17 February 2015; accepted 13 March 2015; published 17 March 2015

Copyright (C) 2015 by authors and Scientific Research Publishing Inc.

This work is licensed under the Creative Commons Attribution International License (CC BY). http://creativecommons.org/licenses/by/4.0/

(c) (i) Open Access

\begin{abstract}
Curcumin is a naturally occurring phytotherapeutic that has broad uses including the treatment of cancer and as a potent antimicrobial agent. Its dynamic ability to treat very different kinds of disease has spawned a significant increase in inquiry on how curcumin accomplishes these feats. Thousands of peer reviewed papers were published in the past few years regarding the various functions of curcumin. Unlike most pharmaceuticals, curcumin has a multi-range of different targets that it interacts with. Since curcumin's bioavailabilty is limited, methods of increasing curcumin's bioavailabilty are discussed. Mechanisms of action regarding curcumin's ability to effect cancer are discussed including upstream and downstream mechanisms starting with epigenetics to its effect on signal transduction pathways and apoptosis. Curcumin also works adjuvantly with chemotherapy to reduce resistance and enhance the mechanism of certain chemotherapeutic agents. Curcumin's antibacterial, antifungal, and antiviral capability is also discussed with regard to curcumin's dynamic ability to treat infections. Curcumin use in cancer adjunctive care and its anti-infectious capabilities make it a unique phytotherapeutic agent with promise.
\end{abstract}

\section{Keywords}

Curcumin, Cancer, Chemotherapy, Anti-Inflammatory, Antimicrobial, Cyclodextrin

\section{Introduction}

Naturally occurring phytochemicals have long since been used to treat various diseases. To this day, many drug

\footnotetext{
${ }^{*}$ Corresponding author.
}

How to cite this paper: Smith, A.J., Oertle, J. and Prato, D. (2015) Multiple Actions of Curcumin Including Anticancer, Anti-Inflammatory, Antimicrobial and Enhancement via Cyclodextrin. Journal of Cancer Therapy, 6, 257-272. 
candidates begin as naturally occurring agents used in traditional medicine [1]. Curcumin is a yellow pigment found in turmeric and has been used for centuries for various ailments in addition to a food preservative. Some of the traditional ailments that curcumin was used to treat included upset stomach, dysentery, jaundice, arthritis sprains, wounds, acne, and infections of the skin or eyes [2]. Thousands of years after curcumin's initial use to treat ailments the structure was discovered 1910 by the German scientist J Milobedzka and V Lampe. Since then there has been a recent surge in research associated with curcumin. Thousands of papers have been published in the past few years alone focusing primarily on curcumin's anticancer and antimicrobial capabilities but also psychophysiological, inflammation, and diabetes among others.

Administration of curcumin in its natural form has limitations associated with its limited bioavailability. There are several analogs of curcumin that have since been synthesized to increase the bioavailability of curcumin. Such methods include PEGalating curcumin to increase solubility and bioavailbility. This review will also only focus on the curcumin itself and not demothoxycurcumin or bis-demotheoxycurcumin. These curcumin analogs clearly have a different structure and are beyond the scope of this paper.

\section{Cancer}

The cause of cancer is genetics. Genetic mutations in oncogenes and tumor suppressor genes are monitored to better understand what is happening in any particular cancer. Although treating the gene itself is essentially off the table, there are ways to treat the outcome of these mutations via influencing epigenetics or influencing the enzymes, proteins, and their respective metabolites. Curcumin is rather unique that it can influence a variety of mechanisms associated with cancer including epigenetic causes as well as more traditional targets of cancer.

\section{Epigenetics and Cancer}

The three major interconnected methods of regulating gene expression in eukaryotes via epigenetics include DNA methylation, histone modifications, and miRNA expression [3]-[5]. These methods, as related to cancer, involve the up regulation or activation of proto-oncogenes or genes associated with tumor progression. In cancer, epigenetics also influences tumor suppressor gene expression by silencing them. This is often caused by hypermethylation of the tumor suppressor genes promoter region [6]-[8]. Histone modifications may involve acetylation, ADP-ribosylation, ubiquitination, and sumoylation in either the $\mathrm{N}$ - or C-terminal tail domains [9] [10]. Such histone modifications influence the structure and function of the chromatin in a way that also influences gene transcription, DNA repair, and DNA replication [11] [12]. Activation of genes through histone modification is primarily associated with the extent the chromatin is acetylated where acetylated chromatin is considered open while deacetylated chromatin is considered closed. Like methylation of DNA, acetylation of histones is reversible. miRNA are a significant regulator of genes by posttranscriptional control of gene expression by complementarily binding to mRNA in a manner the blocks the mRNAs translation respectively and therefore can influence the translation of tumor suppressor genes. If mutated, miRNA has the potential to act as novel form of oncogenic or tumor suppressor genes [13]-[15].

As mentioned above, DNA methylation, particularly in the promoter region of a gene, can cause genes to be silenced. This is particularly problematic if the gene is a tumor suppressor gene. Hypermethylation is associated with oxidative stress within cells. However, DNA methylation of tumor suppressor genes by random action can also lead to gene silencing. In any event, since the process of methylation is reversible by active or passive DNA demethylation, epigenetics is dynamic with an opportunity to reverse epigenetic causes of cancer.

There are few experiments that have shown that curcumin has an effect on the epigenetics of cancer methylation markers. CpG methylation of the promoter region of Neurog1within LNCaP cell lines was shown to be reversed in the presence of $5 \mu \mathrm{M}$ of curcumin. Research suggests that the DNA methyltransferase (DNMT) was inhibited by curcumin in this case [16]. In MV4-11 leukimia cell lines, global hypomethylation was observed. Such observations supports analysis related to curcumin covalently blocking DNMT1 in a concentration of 30 $\mathrm{nM}$ after a period of treatment for $72 \mathrm{~h}$ [17]. Other experimentations involving SiHa ovarian cancer cells administered with $50 \mu \mathrm{M}$ of curcumin further validates this observation the M SssI, an analog of DMTI, was inhibited when exposed to curcumin [18]. DNMT1 down regulation at the mRNA and protein level was also observed in melanoma cells [19] and in MCF-7 breast cancer cells [20]. Hypomethylation of miRNA promoter region miR-203 in cancer cells associated with bladder cancer in the presence of $10 \mu \mathrm{M}$ of curcumin was observed is another way curcumin impacts the epigenetics of cancer cells [21]. 
Histones describe the components of chromatin and are designated as H1, H2A, H2B, H3, and H4. These proteins are highly conserved with significant functions ranging from chromatin remodeling as it relates to transcription, replication, and repair. As mentioned earlier, histones are subject to post translational modifications in either their $\mathrm{N}$ or $\mathrm{C}$ terminal tail domains [22] [23]. Acetylation of chromatin by histone acetyl transferaces (HATs) are most associated with genes being open for transcription while deacetylation by histone deacetylases (HDACs) are most associated with a gene being closed.

Targeting and regulating histone modifying enzymes as a means to treat cancer are already available for cancer patients [24]. Curcumin has the capacity to induce acetylation of histone $\mathrm{H} 3$ and $\mathrm{H} 4$ at a concentration ranging from $10-30 \mu \mathrm{M}$ which suggests that curcumin has the potential to regulate genes related to cell survival and apoptosis [25]. Evidence of histone hypoacetylation by curcumin was observed to cause apoptotic cell death through PARP- and caspase-3-mediated manner in brain glioma cells [26]. Inhibition of p300 activity in the TREM-1 promoter directing H3 and H4 hypoacetylation was reported as an epigenetic shift associated with curcumin administration [27]. Curcumin can also significantly reduce HAT activity in addition to stopping nuclear transcription factor- $\kappa$ mediated chromatin acetylation when curcumin is administered at $1.5-12.5 \mu \mathrm{M}$ for a period of $72 \mathrm{~h}[28]$.

miRNAs are characterized by their noncoding 19 - 25 nucleotide length which serves to post-transcriptionally regulate mRNA functioning. RNA induced silencing complex occur after mature miRNA assemble with the multi-protein effector. miRNA works by either causing transcriptional degradation or by blocking translation [13] [29] [30]. The gene loci of miRNA are frequently located by tumor suppressor genes and oncogenes as evidence of a link between oncogenesis and cancer progression to miRNA expression [31]. The detection and treatment of cancer via monitoring the expression of miRNA has future potential [32] [33].

Cell death by apoptosis of leukemia and breast cancer cells by curcumin's influence on miRNA involves the up regulation miR-15a and miR16 which impacts antiapoptotic Bcl-2 by decreasing its expression in addition to down regulating WT1 expression which is associated with leukemogenesis [34] [35]. Cisplatin A549/DDP multidrug resistant cells' expression of 342 miRNAs was altered by curcumin in a manner that inhibits the oncomir miRNA-186* [36] [37]. Gemicitabine-resistant pancreatic cancer cell lines have down regulated miR-21 in the presence of 1 - $4 \mu \mathrm{M}$ of curcumin for $72 \mathrm{~h}$ [38]. Down-regulation of Notch-1-specific miRNAs including miR21 and miR-34a after administration of $30 \mu \mathrm{M}$ of curcumin for a period of $24 \mathrm{~h}$ induces cell death of esophageal cancer [39]. The role of epigenetics and curcumin is dynamic with different aspects of epigenetics influencing other epigenetic regulation of genes. An example would be curcumin activity with regard to the hypomethylation miR-203 promoter which induces the expression miR-203 which is a tumor suppressive miRNA [21].

\section{Cancer Stem Cells}

The tumor stem cells hypothesis has gained momentum due to advances in cell biology. This hypothesis states that in the process of oncogenesis, cancer cells more likely resemble stem cells than the original tissue. This hypothesis more specifically states that cancer arises from normal tissue state and then to stem cell state by aberrant procedures associated with self-renewal [40]. Cancer stem cells have been delineated by their specific function including slow proliferating stem cells, terminally differentiated stem cells, and rapidly proliferating transit amplifying cells [41]. Resistance to chemotherapy drugs, tumor genesis, and tumor recurrence are driven by cancer stem cells.

Curcumin affects cancer stem cells in a few ways. The morphology of the cancer stem cells are influenced by curcumin in a manner that inhibits the characteristic sphere shape in several cancers including cancers that express the biomarkers CD133, CD44, CD166, and ALDH1 [42]-[47]. Drug resistant cancer cells can be sensitized by curcumin in a manner that aids in the cellular accumulation of chemotherapeutic agents [48]-[52]. More on the topic of chemosensitization properties will be discussed in greater detail later in the text. There is also potential that curcumin can influence variety of differentiated cancer stem cells rather than only targeting just one specific cell line. The inhibition of cellular growth by curcumin by affecting the whole cell population respectively leads to the inhibition of differentiated daughter cells as well as a decrease in stem-like cancer cells.

\section{Kinds of Cancer}

There are various types of cancers that can be treated with curcumin. The cancers listed and the microbes that can be treated by curcumin are not exhausted but still offers a sample of what curcumin can do. It is also impor- 
tant to recognize that many of the mechanisms of curcumin are similar across the various kinds of cancers and therefore the biomarkers of each cancer should be of focus rather than the kind of cancer itself.

\section{Lung}

Significant inhibition of proliferation of cancer cell lines A549 and H460 were observed in vitro after administration of curcumin. Curcumin elevates FOXO3a target gene expression in A549 cancer cells including Bim, p21, and p27 which in turn decreases the level of cyclin D1 in addition to increasing the level of activated caspase-3 which is involved in the suppression of proliferation [53]. Cell viability was also reduced as seen in results associated with the down regulation of expression eIF2 $\alpha$ and eIF4E [54]. Down regulation of neutrophil elastase and the up regulation of $\alpha 1$-antitrypsin in mice treated with curcumin is significant in the inhibition of cancer cell growth [55]. Curcumin down regulates Cdc42 which is associated with cellular transformation, proliferation, survival, metastasis, and invasion in lung cancer [56]. Curcumin suppresses cell metastasis via a mechanism by blocking NF-кB, which is associated with cellular inflammation, and inhibiting HDACi [57].

\section{Breast}

Breast cancer is the most common cancer among both pre and post-menopausal women. Curcumin has the effect of down regulating several genes associated with breast cancer including NF- $\mathrm{B}, \mathrm{AP}-1$, Cox-1, VEGF, cyclin E, fibroblast growth factor (FGF), IL-6, IL-11, MMP-2, MMP-9, and MMP-13 and the up-regulation of P21 and P27 [58] [59]. Curcumin is also known to inhibit the reverse transcriptase activity of telomerase in addition to the induction of apoptosis of breast cancer cells by via p53-dependent Bax expression [59]. MDA-MB-231/Her2 cells administered with curcumin showed a decrease in cellular expression of Her2, cyclin E, CDK kinases and Skp2 [60]. Tumor cells pretreated with curcumin showed a reduction of inhibition of IL-2 [61]. The presence of curcumin also showed to arrest cells at the G1 phase in addition to increasing p27 which is associated with the reduction of cellular migration.

\section{Colorectal}

Colorectal cancer is the third leading cause of cancer death. Treatment with curcumin has a number of affects including chromosome condensation, cell shrinkage, and DNA fragmentation via a mechanism associated with promotion of DNA damage-inducible gene (DDIT3) at the mRNA and protein levels of various colon cancer cell lines. Curcumin has also shown to induce apoptosis in addition to inhibiting of proliferation of colon cancer cell lines via down regulation of c-Myc, increased activity of cell division control 2 (CDC2), blocking cell cycle progression with a mechanism associated with cyclin D and cyclin B expression, and capase-3-mediated $\beta$-catenin cleavage [62]. Curcumin is also known to arrest cell cycle and induce apoptosis by decreasing the expression of $\mathrm{PGE}_{2}$ [63]. Inhibition of EGF receptor (EGFR), which inhibits the early growth response in the presence of curcumin, was observed in Caco-2 and HT-29 cell lines were observed [38]. Studies have also shown that an increase in p53 by curcumin is associated with improvement of overall health colorectal cancer patients [64].

\section{Prostate}

The second leading cause of cancer related mortality among men is prostate cancer [3]. Inhibition of angiogenesis, proliferation, and a decrease in microvessel density in LNCap prostate cancer cells was observed when treated with curcumin [65] [66]. Down regulation of antiapoptotic genes including $\mathrm{Bcl}_{2}$ and $\mathrm{Bcl}-\mathrm{xL}$ in addition to up regulation procaspase-3 and procaspase-8 occurred in the same cell lines in the presence of curcumin [67]. Proliferation, colony formation, cellular aggregation, and cell motility in prostate cancer cells is decreased by curcumin via the activation of protein kinase D1 (PKD1) and subsequent inhibition of $\beta$-catenin transcription. Inhibition of $\beta$-catenin is related to the inhibition of cellular growth which means curcumin effects cellular growth downstream from PKD1 respectively [68].

\section{Ovarian}

According to the CDC, ovarian cancer is the fifth leading cause of cancer deaths among women in America in 2014. In cancer cell lines SKOV3ip1, HeyA8, and HeyA8MDR treated with curcumin, inhibition of NF- $\mathrm{B}$ and activation of STAT3 lead to suppressed proliferation. A decrease in angiogenesis and microvessel density in ad- 
dition to an increase in apoptosis was observed in vivo models involving SK0V3ip1 and HeyA8 cells treated with curcumin [69]. The reduction of expression of $\mathrm{Bcl}_{2}$ and survivin, which are antiapoptotic proteins, in addition to the down regulation of Akt signaling and the activation of p38-MAPK was observed during treatment with curcumin [70]. p53-independent apoptosis by curcumin in ovarian carcinoma cells mechanism involved PARP cleavage, DNA fragmentation, nuclear condensation, and activation of procaspsase- $3,-8$, and -9 and its association with cytochrome c release.

\section{Leukemia}

The most common form and the most common cause of cancer related death among children between 0 - 19 years old is Leukemia (CDC). The effects of curcumin in HL-60 cells involve inducing apoptosis from the upregulation of Bax and cytochrome $\mathrm{C}$ in addition to down regulating $\mathrm{Bcl} 2$ which is associated with activation of caspase-3 and caspase-6 plus degradation of PARP [71]. Curcumin also inhibits telomerase in HL-60 cells [71]. Apoptosis of CLL-B cells in the presence of curcumin occurred via a mechanism associated with the inhibition of STAT3, AKT, NF- $\kappa$ B, and X-linked inhibitor of apoptosis protein (XIAP) in addition to the upregulation BIM [59] [72]. Gene expression of Wilms' tumor 1 and multiple drug resistance 1 (MDR1) is also inhibited by curcumin [73].

\section{Multiple Myeloma}

Multiple myeloma (MM) is the $14^{\text {th }}$ leading cause of cancer that disproportionately affects black men in particular. STAT3 nuclear translocation in MM cells is inhibited downstream by curcumin inhibiting IL-6 induced STAT3 phosphorylation [74]. Curcumin is known to induce PARP cleavage, activation of caspase-7 and caspase-9, in addition to arresting the cell cycle G1/S phase [75]. Suppression of Cox-2 and the down regulation of activation of NF-kB occurs when curcumin is administered to patients with MM [76] [77]. Curcumin has also been shown to decrease urinary N-telopeptide from type 1 collagen in more than $25 \%$ of MM patients treated during clinical trials [78].

\section{Chemosensitizing}

Significant amount of time and energy has gone into researching why chemotherapy in particular does not work on certain kinds of cancer. This is particularly true if a chemotherapy regiment has limited effect on reducing tumor size. Quite often these tumors are resistant to a whole host of drugs with different targets, structure, and functionality. These kinds of cancers are known as multidrug resistant (MDR).

There are two forms of MDR cancers; intrinsic and acquired. Intrinsic MDR occurs when the cancer is refractory to chemotherapy at the outset of treatment. Acquired occurs later in treatment after a course of chemotherapy appears to have worked before the cancer relapses to a point where previous working chemotherapy has very little or no effect on the cancers progression.

The mechanism for MDR can occur in two different ways. The first way involves the nullification of cancer drugs by impairing the delivery of anticancer drugs to tumor cells. This can occur when a cancer up regulates its drug efflux transporters in a manner that reduces the amount of chemotherapy in the tumor at any given time in addition to reducing the amount of chemotherapy diffused into the blood stream [79]. The second way is more intrinsic to the cancer cells progression. Cancer cells that mutate at a genetic level or change in expression patterns due to epigenetics are alterations that have the capacity to affect a cancer's drug sensitivity. Another mechanism involves blocking apoptotic pathways and increasing survival pathways in cancers insensitive to chemotherapies that promote cell death by apoptosis. Drug sensitivity and resistance are deeply related in at least one of these pathways [80].

Phytochemicals have a place in the landscape of chemosensitization of chemotherapy to tumors. Curcumin, quercetin, xanthorrhizol, ginger, and genistein all have chemosensitizing properties with remarkably low toxicity [81] [82]. The safety of curcumin and other turmeric products are deemed safe by both the Food and Drug Administration (FDA) as well as the Food and Agriculture Organization (FAO) and World Health Organization (WHO) [83]. Curcumin in particular has been recognized as a candidate with antineoplastic activity among an array of various cancers [84]-[88]. In addition to exerting low toxicity to normal cells, curcumin is known to protect the immune system from immunosuppression associated with cancer [89]-[92].

A major target with respect toward resolving issues with refractory cancer involves modulation, or more spe- 
cifically, the inhibition of ABC drug efflux pumps. ATP driven ABC drug efflux pumps play a significant role in MDR. There have been many candidates to reduce the activity of ABC drug efflux pumps with little or no avail including verapamil, tamoxifen, dexverapamil, valspodar, cyclosporine A, and biricodar [93]. Tumors with overexpression of $\mathrm{ABC}$ transporters $\mathrm{ABCB} 1, \mathrm{ABCG} 2$, and $\mathrm{ABCC} 1$ were reported to become sensitized to chemotherapy by curcumin [94]-[96]. Observations of curcumin blocking the efflux pump in cervical cancer cell lines with overexpression of ABCB1 was also documented using fluorescent substrates including calcein AM, Bodipy-FL vinblastine, and rhodamine 123 [94]-[97].

Curcumin also creates an environment that is advantageous to chemotherapy by directly quenching reactive oxygenated species (ROS) in addition to quenching hydroxyl radicals and superoxide radicals [98]. Glutothione S-transferase (GST) is reduced by curcumin in K-562 cells which is significant to sensitize cancerous cells to chemotherapy [99]. Cancer cells can become more susceptible to toxins by curcumin via inhibition of phase 1 enzyme systems which includes cytochrome P450 isoforms, cytochrome b5, and the P450 reductase in addition to epoxide hydrolase [100].

Curcumin also has the potential to sensitize cancers to TRAIL-induced apoptosis by both intrinsic and extrinsic apoptotic pathways in ovarian cancer cells [101] in addition to congruent results in LNCaP prostate cancer cells [102]. Administration of curcumin LNCaP, DU145, and PC3 prostate cancer cell lines increased the sensitivity to TRAIL by inhibition of NF-kB by blocking the phosphorylation to I $\mathrm{B} B \alpha$ [102]-[104]. TRAIL was also targeted by curcumin in U87 glioma cells [105]. TRAIL-resistant LNCaP xenografts cell death associated with the administration of curcumin also underwent apoptosis via TRAIL mediated cell death [106]. As mentioned before, inactivation of NF- $\mathrm{kB}$ by curcumin also has an effect on pro-inflammatory cytokines including IL-1, IL-2, IL-6, and IL-8 [107].

Resistance to chemotherapy associated with aberrations in the p53 network is a common target for chemotherapies. Glioma cells can be sensitized to chemotherapies which include cisplatin, camptothecin, doxorubicin, and etoposide by curcumin via inhibition of the expression of BCL2 and IAP; which are associated with the p53 family [108]. A reduction of dosage of cisplatin in cisplatin-resistant ovarian cancer cells was also seen when the cells were pretreated for $6 \mathrm{~h}$ with curcumin by down-regulating the BCL-XL. Pretreatment of curcumin also activated caspase-9 and caspase-3, increased the expression of BAX, and down regulated the expression of BCL and BCL-XL [109]. Breast cancer cells treated with curcumin also exhibited loss of mitochondrial transmembrane potential and initiation of the death cascade.

\section{Anti-Inflammatory}

Curcumin has the potential to interact with several molecular targets associated with inflammation. Cyclooxygenase-2 (Cox-2) and lipoxygenase down regulation and the induction of nitric oxide synthase (iNOS) are associated with the inhibition tumor necrosis factor-alpha (TNF- $\alpha$ ), IL-1, -2, -6, -8, and -12), migration inhibitory protein, and monocyte chemoattractant protein (MCP) in addition to the down regulation of Janus and mitogen-activated kinase [110] [111]. Suppression of NF-kB is likely the cause of COX-2 and iNOS inhibition [112]. The down regulation of COX-2 and iNOS expression amy cause the inhibition of tumorgenesis and inflammation [112] [113]. Down regulation of lipoxygenase and cyclooxygenase pathways from curcumin in animal models are associated with the inhibition of aracadonic acid metabolism and inflammation [114]. The inhibition of cytokine expression by curcumin involves a mechanism associated with the regulation of transcription factor activation of NF- $\mathrm{kB}$ and activating protein-1 (AP-1).

The impact of inflammation and the promotion of tumors have been well documented [115] [116]. Curcumin's ability to reduce inflammation makes it a strong candidate for chemopreventative activity associated with tumor-genesis. Colorectal, gastric, pancreatic, breast, prostate, and oral cancers as well as leukemia carcinogenesis are inhibited by curcumin in various stages of carcinogenesis [117]. Protein kinase C inhibition which is associated with mediation of inflammation and tumor cell proliferation is another mechanism influenced by curcumin [118]. Inflammatory cytokines including TNF- $\alpha$, IL- $1 \beta$, and IL-6 are also inhibited and are associated with inhibition of cancer cell lines [119].

\section{Antioxidant}

Extensive researches on the antioxidant capacity of curcumin have been done on rat and mice models. Increased lipid peroxidation in mice exposed to $\mathrm{CCL}_{4}$, paraquat, and cyclophosphamide had reduced levels of lipid perox- 
idation as compared to the control [120]. Serum and lipid peroxides were reduced by curcumin in rat models on a diet of unsaturated fats when given curcumin for 8 weeks [121]. In another model involving rats fed unsaturated fats, lipid peroxides were also reduced and antioxidant enzymes were enhanced [122]. Oxidative stress induced by alcohol was reduced in rats given curcumin daily [123]. A delayed development of cataract due to oxidative damage of the eye lens was observed in rats given curcumin and selenium [124]. A reduction in lipid peroxidation in both serum and liver of irradiated rats given curcumin orally was also observed [125].

\section{Antimicrobial}

The antimicrobial effects of curcumin are well documented and have been utilized for centuries. The following sections describe the antibacterial, antiviral, and antifungal activities of curcumin by itself or in conjunction with other antimicrobials.

\section{Antibacterial}

Curcumin and various extracts of $C$. longa and more specifically turmeric have been studied with regard to their antibacterial properties. Of these various extracts, hexane and ethanol extract of turmeric (85\% curcuminoid) was studied in 24 pathogenic bacteria and it was found that the extract had a minimum inhibitory concentration (MIC) value ranging from 3.91 to 125 ppt [126]. Focusing back on curcumin by itself, methicillin-resistant Staphylococcus aureus (MRSA) was shown to have been inhibited by curcumin with and MIC value of 125 - 250 $\mu \mathrm{g} / \mathrm{ml}$ [127]. Induction by filamentation by suppressing cytokines of $B$. subtilis was observed when treated with curcumin. The treatment of curcumin to $B$. subtilis showed a reduction of the bundling of FtsZ protofilaments and its associated dissociation constant [128]. The inhibition of FtsZ polymerization has the potential to suppress FtsZ assembly in both E. coli and B. subtilis in a manner that disrupts cellular division [129]. Although curcumin has antibacterial attributes in $H$. pylori, curcumin does eradicate H. pylori nearly as well as Omeprazole, Amoxicillin, and Metronidazole. However, when curcumin is taken with ampicillin against $S$. aureus there is a synergistic effect associated with the reduction of MIC. Synergistic effects with ampicillin, oxacillin, and norfloxacin were observed when administered against MRSA [127].

\section{Antiviral}

There are several mechanisms associated with curcumin's capacity of inhibition of viruses in several strains with minimal toxicity to cells. HIV-1 LTR-directed gene expression was inhibited by curcumin without a significant effect on cell viability [130]. However, in clinical trials, curcumin was not able to reduce viral load in HIV patients. Anti-influenza activity was seen in PR8, H1N1, and H6N1 strains by reducing the viral yield in cell culture in the presence of $30 \mu \mathrm{M}$ of curcumin. The $\mathrm{EC}_{50}$ for the influenza virus was found to be $470 \mathrm{nM}$ of curcumin [131]. Herpes simplex virus-1 (HSV-1) was also affected by curcumin exhibiting an $\mathrm{IC}_{50}$ of $33.0 \mu \mathrm{g} / \mathrm{ml}$ by reducing HSV-1 replication [132] [133]. Curcumin inhibited the expression of human papilloma virus (HPV)-16 and HPV-18 oncogenes E6 and E7, making curcumin a strong candidate for managing HPV infections [134] [135]. Although further investigation is needed, Japanese encephalitis virus (JEV) ubiquitin-proteosome system was inhibited in Neuro2a cell lines by curcumin [136].

\section{Antifungal}

Fungal related spoilage of food has been remedied for centuries using turmeric and curcumin. Research has confirmed the extensive traditional usage of turmeric powder to inhibit the growth of fungi and overall fungi contamination at concentrations of 0.8 and $1.0 \mathrm{~g} / \mathrm{L}$ [137]. Although turmeric and turmeric extracts using various solvents show promise with regard to antifungal activity, the focus of this section will be more specifically on the effects of curcumin rather than various crude extracts.

The emergence of resistant strains of Candida species has brought with it significant challenges with regard to treatment with antifungal agents and thus created an emphasis on finding new antifungal treatments [138]. Curcumin was found to be a potent fungicide of over 14 strains of Candida species with MIC values ranging from $250-2000 \mu \mathrm{g} / \mathrm{ml}$ [139]. A possible mechanism associated with cell death may involve inhibition of $\mathrm{H}^{+}$extrusion causing intercellular acidification [140]. In addition to that, inhibition of the development of hyphae by curcumin was observed with a mechanism associated with its effect on global suppressor thymidine uptake 1 (TUP1) 
[141] [142]. Inhibition of Cryptococcus neoformans and C. dubliniensis was observed with an MIC value of 32 $\mathrm{mg} / \mathrm{L}$ of curcumin.

Reduction of MIC values due to synergistic effects of curcumin and common antifungal agents was observed in 21 clinical isolates of C. albincans. These drugs administered with curcumin included voriconazole, itraconazole, ketoconazole, miconazole, fluconazole, amphotericin B, and nystatin and showed a decrease in MIC values between 10 - 35 times that of the traditional antifungal agents alone. Systemic fungal infections, like those associated with candidemia and candidosis, can be treated with existing fungicidal agents and curcumin to have a greater antifungal effect [143].

\section{Cyclodextrin}

The bioavailability of curcumin is very low (1\% bioavailability) with the vast majority of curcumin being excreted in feces. For this reason, there are abundant variations to increase its delivery. One of the most prominent methods of increased delivery is using cyclodextrin. Cyclodextrin are composed of sugar molecules bound together to form cyclic oligosaccharides [144] Small molecules like curcumin can form water soluble inclusion complexes [145]. The interior of cyclodextrin is hydrophobic and an exterior that is water soluble, creating a pocket for hydrophobic molecules like curcumin to enter, making curcumin respectively water soluble. These results were verified by caning spectrophotometer techniques in addition to observing the complex using high speed liquid chromatography and UV/VIS scanning spectrophotometer [146]. Cyclodextrin can be thought of as vehicles in a manner that aids bioavailability in addition to protecting curcumin from degradation without any alterations to the chemical structure of curcumin [147]. The solubility of curcumin in PBS solution is approximately $20 \mu \mathrm{g} / \mathrm{ml}$ while the solubility of curcumin and cyclodextrin is up to $600 \mu \mathrm{g} / \mathrm{ml}$ [148]. This increase in solubility is significant in absorption of curcumin in vivo.

Cyclodextrin and curcumin were shown to not only increase solubility but to also increase the inhibition of NF-kB which is associated, among other things, with inflammation [149]. Cyclodextrin and curcumin were also able to suppress cyclin D1, vascular endothelial growth factor (VEGF), and matrix metallopeptidase 9 (MMP-9). Greater activity in initiating cell death receptors and an increase in apoptosis in several cancer cell lines including leukemia in comparison to free curcumin was also observed when administered cyclodextrin and curcumin. These findings suggest that uptake of curcumin increased cellular uptake as well as anti-inflammatory and anti-proliferative effects when coupled with cyclodextrin [149].

\section{Discussion}

It is clear that curcumin has a place in modern medicine to treat various diseases including cancer. To our knowledge there are no drugs that work as broadly, particularly for chemotherapy. It is rare to find such a compound that has the vast functionality like curcumin. Curcumin acts both upstream and downstream in the progression of cancer. The antioxidant and anti-inflammatory aspect of curcumin has the potential to reduce the likelihood of developing cancer. Inflammation itself can be caused by a myriad of chemicals and microorganisms. Such inflammation is linked to an increase likelihood of developing cancer but the exact mechanism remains unresolved. Inflammation is linked to epigenetic changes which have the potential to cause cancer. Curcumin's ability to effect the epigenetics of cancer cells in addition to mechanisms of attacking cancer stem cells is significant in early treatment of cancer with remarkably very low toxicity to the patients. Once cancer develops, curcumin can treat various forms of cancer and even work to enhance the effects of chemotherapy. Late stages of cancer that are resistant to chemotherapies may become sensitized by curcumin, offering an opportunity to treat various late stage cancers.

The use of curcumin to treat microbes has been used for centuries. The effect of curcumin on various microbes has been well documented. Although there is significant literature on curcumin and its antimicrobial activity, there is still more research that needs to be done in order to determine how many microbes could be affected by curcumin. Stubborn diseases including an infection by MRSA can be sensitized to antibiotics when administered with curcumin. This shows promise with regard to making curcumin a candidate to potentially enter the mainstream medicine. The use of curcumin as a preservative, particularly against fungi, has been used for centuries and may offer an opportunity for it to become more main stream if given proper consideration.

The solubility and low bioavailablity of curcumin is an issue that has been traditionally been resolved by offering higher insufficient doses of curcumin. There are various methods involving nanotechnology to increase 
the solubility and bioavailability of curcumin. Among those is the use of cyclodextrin to alleviate this issue. Cyclodextrin is safe in that it is comprised of a ring of sugar molecules that does not react with the body in any known or appreciable manner. Studies have shown that the use of cyclodextrin to shuttle curcumin does not interfere with the curcumin's ability to reach cells and in some cases actually increases the effect of curcumin.

\section{Conclusion}

Curcumin is a promising candidate to treat many ailments including cancer. This review is not all encompassing paper with regard to everything that is known about curcumin but does serve to highlight key aspects that make curcumin an attractive candidate for treatment. We believe that treatment involving curcumin and more specifically treatment involving curcumin using nanotech delivery systems should be actively considered particularly for treatment of cancer or adjunctive treatment of cancer. Methods including the use of cyclodextrin with curcumin should be investigated further as the combination appears to be very promising.

\section{References}

[1] Corson, T.W. and Crews, C.M. (2007) Molecular Understanding and Modern Application of Traditional Medicines: Triumphs and Trials. Cell, 130, 769-774. http://dx.doi.org/10.1016/j.cell.2007.08.021

[2] Singh, S. (2007) From Exotic Spice to Modern Drug? Cell, 130, 765-768. http://dx.doi.org/10.1016/j.cell.2007.08.024

[3] Sawan, C., Vaissiere, T., Murr, R., Herceg, Z. (2008) Epigenetic Drivers and Genetic Passengers on the Road to Cancer. Mutation Research, 642, 1-13. http://dx.doi.org/10.1016/j.mrfmmm.2008.03.002

[4] Cameron, E.E., Bachman, K.E., Myohanen, S., Herman, J.G., et al. (1999) Synergy of Demethylation and Histone Deacetylase Inhibition in the Re-Expression of Genes Silenced in Cancer. Nature Genetics, 21, 103-107. http://dx.doi.org/10.1038/5047

[5] Davis, C.D. and Ross, S.A. (2007) Dietary Components Impact Histone Modifications and Cancer Risk. Nutrition Reviews, 65, 88-94. http://dx.doi.org/10.1111/j.1753-4887.2007.tb00285.x

[6] Ehrlich, M. (2009) DNA Hypomethylation in Cancer Cells. Epigenomics, 1, 239-259. http://dx.doi.org/10.2217/epi.09.33

[7] Kulis, M. and Esteller, M. (2010) DNA Methylation and Cancer. Advances in Genetics, 70, 27-56. http://dx.doi.org/10.1016/B978-0-12-380866-0.60002-2

[8] Mani, S. and Herceg, Z. (2010) DNA Demethylating Agents and Epigenetic Therapy of Cancer. Advances in Genetics, 70, 327-340. http://dx.doi.org/10.1016/B978-0-12-380866-0.60012-5

[9] Strahl, B.D. and Allis, C.D. (2000) The Language of Covalent Histone Modifications. Nature, 403, 41-45. http://dx.doi.org/10.1038/47412

[10] Bannister, A.J. and Kouzarides, T. (2011) Regulation of Chromatin by Histone Modifications. Cell Research, 21, 381-395. http://dx.doi.org/10.1038/cr.2011.22

[11] Kouzarides, T. (2007) Chromatin Modifications and Their Function. Cell, 128, 693-705. http://dx.doi.org/10.1016/j.cell.2007.02.005

[12] Sawan, C. and Herceg, Z. (2010) Histone Modifications and Cancer. Advances in Genetics, 70, 57-85. http://dx.doi.org/10.1016/B978-0-12-380866-0.60003-4

[13] Vandenboom II, T.G., Li, Y., Philip, P.A. and Sarkar, F.H. (2008) MicroRNA and Cancer: Tiny Molecules with Major Implications. Current Genomics, 9, 97-109. http://dx.doi.org/10.2174/138920208784139555

[14] Fabbri, M. and Calin, G.A. (2010) Epigenetics and miRNAs in Human Cancer. Advances in Genetics, 70, 87-99. http://dx.doi.org/10.1016/B978-0-12-380866-0.60004-6

[15] Winter, J. and Diederichs, S. (2011) MicroRNA Biogenesis and Cancer. Methods in Molecular Biology, 676, 3-22. http://dx.doi.org/10.1007/978-1-60761-863-8_1

[16] Shu, L., Khor, T.O., Lee, J.H., Boyanapalli, S.S., Huang, Y., Wu, T.Y., et al. (2011) Epigenetic CpG Demethylation of the Promoter and Reactivation of the Expression of Neurog1 by Curcumin in Prostate LNCaP Cells. AAPS Journal, 13, 606-614. http://dx.doi.org/10.1208/s12248-011-9300-y

[17] Liu, Z., Xie, Z., Jones, W., Pavlovicz, R.E., Liu, S.J., Yu, J.H., et al. (2009) Curcumin Is a Potent DNA Hypomethylation Agent. Bioorganic \& Medicinal Chemistry Letters, 19, 706-709. http://dx.doi.org/10.1016/j.bmcl.2008.12.041

[18] Parashar, G., Parashar, N.C. and Capalash, N. (2012) Curcumin Causes Promoter Hypomethylation and Increased Expression of FANCF Gene in SiHa Cell Line. Molecular and Cellular Biochemistry, 365, 29-35. http://dx.doi.org/10.1007/s11010-012-1240-z 
[19] Abusnina, A., Keravis, T., Yougbare, I., Bronner, C. and Lugnier, C. (2011) Anti-Proliferative Effect of Curcumin on Melanoma Cells Is Mediated by PDE1A Inhibition that Regulates the Epigenetic Integrator UHRF1. Molecular Nutrition \& Food Research, 55, 1677-1689. http://dx.doi.org/10.1002/mnfr.201100307

[20] Du, L., Xie, Z., Wu, L.C., Chiu, M., Lin, J., Chan, K.K., et al. (2012) Reactivation of RASSF1A in Breast Cancer Cells by Curcumin. Nutrition and Cancer, 64, 1228-1235. http://dx.doi.org/10.1080/01635581.2012.717682

[21] Saini, S., Arora, S., Majid, S., Shahryari, V., Chen, Y., Deng, G.R., et al. (2011) Curcumin Modulates MicroRNA203-Mediated Regulation of the Src-Akt Axis in Bladder Cancer. Cancer Prevention Research, 4, 1698-1709. http://dx.doi.org/10.1158/1940-6207.CAPR-11-0267

[22] Strahl, B.D. and Allis, C.D. (2000) The Language of Covalent Histone Modifications. Nature, 403, 41-45. http://dx.doi.org/10.1038/47412

[23] Bannister, A.J. and Kouzarides, T. (2011) Regulation of Chromatin by Histone Modifications. Cell Research, 21, 381395. http://dx.doi.org/10.1038/cr.2011.22

[24] Manzo, F., Tambaro, F.P., Mai, A. and Altucci, L. (2009) Histone Acetyltransferase Inhibitors and Preclinical Studies. Expert Opinion on Therapeutic Patents, 19, 761-774. http://dx.doi.org/10.1517/13543770902895727

[25] Shankar, S. and Srivastava, R.K. (2007) Involvement of Bcl-2 Family Members, Phosphatidylinositol 3'-Kinase/AKT and Mitochondrial P53 in Curcumin (Diferulolylmethane)-Induced Apoptosis in Prostate Cancer. International Journal of Oncology, 30, 905-918.

[26] Kang, S.K., Cha, S.H. and Jeon, H.G. (2006) Curcumin-Induced Histone Hypoacetylation Enhances Caspase-3-Dependent Glioma Cell Death and Neurogenesis of Neural Progenitor Cells. Stem Cells and Development, 15, 165-174. http://dx.doi.org/10.1089/scd.2006.15.165

[27] Yuan, Z., Syed, M.A., Panchal, D., Rogers, D., Joo, M. and Sadikot, R.T. (2012) Curcumin Mediated Epigenetic Modulation Inhibits TREM-1 Expression in Response to Lipopolysaccharide. International Journal of Biochemistry \& Cell Biology, 44, 2032-2043. http://dx.doi.org/10.1016/j.biocel.2012.08.001

[28] Yun, J.M., Jialal, I. and Devaraj, S. (2011) Epigenetic Regulation of High Glucose-Induced Proinflammatory Cytokine Production in Monocytes by Curcumin. Journal of Nutritional Biochemistry, 22, 450-458. http://dx.doi.org/10.1016/j.jnutbio.2010.03.014

[29] Croce, C.M. (2009) Causes and Consequences of MicroRNA Dysregulation in Cancer. Nature Reviews Genetics, 10, 704-714. http://dx.doi.org/10.1038/nrg2634

[30] Karius, T., Schnekenburger, M., Dicato, M. and Diederich, M. (2012) MicroRNAs in Cancer Management and Their Modulation by Dietary Agents. Biochemical Pharmacology, 83, 1591-1601. http://dx.doi.org/10.1016/j.bcp.2012.02.004

[31] Calin, G.A., Sevignani, C., Dumitru, C.D., Hyslop, T., Noch, E., Yendamuri, S., et al. (2004) Human MicroRNA Genes Are Frequently Located at Fragile Sites and Genomic Regions Involved in Cancers. Proceedings of the National Academy of Sciences of the United States of America, 101, 2999-3004. http://dx.doi.org/10.1073/pnas.0307323101

[32] Negrini, M., Ferracin, M., Sabbioni, S. and Croce, C.M. (2007) MicroRNAs in Human Cancer: From Research to Therapy. Journal of Cell Science, 120, 1833-1840. http://dx.doi.org/10.1242/jcs.03450

[33] Li, Y., Kong, D., Wang, Z. and Sarkar, F.H. (2010) Regulation of MicroRNAs by Natural Agents: An Emerging Field in Chemoprevention and Chemotherapy Research. Pharmaceutical Research, 27, 1027-1041. http://dx.doi.org/10.1007/s11095-010-0105-y

[34] Yang, J., Cao, Y., Sun, J. and Zhang, Y. (2010) Curcumin Reduces the Expression of Bcl-2 by Upregulating miR-15a and miR-16 in MCF-7 Cells. Medical Oncology, 27, 1114-1118. http://dx.doi.org/10.1007/s12032-009-9344-3

[35] Gao, S.M., Yang, J.J., Chen, C.Q., Chen, J.J., Ye, L.P., Wang, L.Y., et al. (2012) Pure Curcumin Decreases the Expression of WT1 by Upregulation of miR-15a and miR-16-1 in Leukemic Cells. Journal of Experimental \& Clinical Cancer Research, 31, 27. http://dx.doi.org/10.1186/1756-9966-31-27

[36] Tang, N., Zhang, J. and Du, Y. (2010) Curcumin Promoted the Apoptosis of Cisplain-Resistant Human Lung Carcinoma Cells A549/DDP through Down-Regulating miR-186*. Zhongguo Fei Ai Za Zhi, 13, 301-306.

[37] Zhang, J., Zhang, T., Ti, X., Shi, J., Wu, C.G., Ren, X.L. and Yin, H. (2010) Curcumin Promotes Apoptosis in A549/ DDP Multidrug-Resistant Human Lung Adenocarcinoma Cells through an miRNA Signaling Pathway. Biochemical and Biophysical Research Communications, 399, 1-6. http://dx.doi.org/10.1016/j.bbrc.2010.07.013

[38] Ali, S., Ahmad, A., Banerjee, S., Padhye, S., Dominiak, K., Schaffert, J.M., et al. (2010) Gemcitabine Sensitivity Can Be Induced in Pancreatic Cancer Cells through Modulation of miR-200 and miR-21 Expression by Curcumin or Its Analogue CDF. Cancer Research, 70, 3606-3617. http://dx.doi.org/10.1158/0008-5472.CAN-09-4598

[39] Subramaniam, D., Ponnurangam, S., Ramamoorthy, P., Standing, D., Battafarano, R.J., Anant, S. and Sharma, P. (2012) 
Curcumin Induces Cell Death in Esophageal Cancer Cells through Modulating Notch Signaling. PLoS ONE, 7, e30590. http://dx.doi.org/10.1371/journal.pone.0030590

[40] Tan, B.T., Park, C.Y., Ailles, L.E. and Weissman, I.L. (2006) The Cancer Stem Cell Hypothesis: A Work in Progress. Laboratory Investigation, 86, 1203-1207. http://dx.doi.org/10.1038/labinvest.3700488

[41] Polyak, K. and Hahn, W.C. (2006) Roots and Stems: Stem Cells in Cancer. Nature Medicine, 12, 296-300. http://dx.doi.org/10.1038/nm1379

[42] Kakarala, M., Brenner, D.E., Korkaya, H., Cheng, C., Tazi, K., Ginestier, C., et al. (2010) Targeting Breast Stem Cells with the Cancer Preventive Compounds Curcumin and Piperine. Breast Cancer Research and Treatment, 122, 777-785. http://dx.doi.org/10.1007/s10549-009-0612-x

[43] Nautiyal, J., Kanwar, S.S., Yu, Y. and Majumdar, A.P. (2011) Combination of Dasatinib and Curcumin Eliminates Chemo-Resistant Colon Cancer Cells. Journal of Molecular Signaling, 6, 7. http://dx.doi.org/10.1186/1750-2187-6-7

[44] Yu, Y., Kanwar, S.S., Patel, B.B., Nautiyal, J., Sarkar, F.H. and Majumdar, A.P. (2009) Elimination of Colon Cancer Stem-Like Cells by the Combination of Curcumin and FOLFOX. Translational Oncology, 2, 321-328.

[45] Fong, D., Yeh, A., Naftalovich, R., Choi, T.H. and Chan, M.M. (2010) Curcumin Inhibits the Side Population (SP) Phenotype of the Rat C6 Glioma Cell Line: Towards Targeting of Cancer Stem Cells with Phytochemicals. Cancer Letters, 293, 65-72. http://dx.doi.org/10.1016/j.canlet.2009.12.018

[46] Pastrana, E., Silva-Vargas, V. and Doetsch, F. (2011) Eyes Wide Open: A Critical Review of Sphere-Formation as an Assay for Stem Cells. Cell Stem Cell, 8, 486-498. http://dx.doi.org/10.1016/j.stem.2011.04.007

[47] Klonisch, T., Wiechec, E., Hombach-Klonisch, S., Ande, S.R., Wesselborg, S., Schulze-Osthoff, K. and Los, M. (2008) Cancer Stem Cell Markers in Common Cancers: Therapeutic Implications. Trends in Molecular Medicine, 14, 450-460. http://dx.doi.org/10.1016/j.molmed.2008.08.003

[48] Li, L., Ahmed, B., Mehta, K. and Kurzrock, R. (2007) Liposomal Curcumin with and without Oxaliplatin: Effects on Cell Growth, Apoptosis, and Angiogenesis in Colorectal Cancer. Molecular Cancer Therapeutics, 6, 1276-1282. http://dx.doi.org/10.1158/1535-7163.MCT-06-0556

[49] Howells, L.M., Mitra, A. and Manson, M.M. (2007) Comparison of Oxaliplatin- and Curcumin-Mediated Antiproliferative Effects in Colorectal Cell Lines. International Journal of Cancer (Journal International Du Cancer), 121, 175-183. http://dx.doi.org/10.1002/ijc.22645

[50] Howells, L.M., Sale, S., Sriramareddy, S.N., Irving, G.R., Jones, D.J.L., Ottley, C.J., et al. (2011) Curcumin Ameliorates Oxaliplatin-Induced Chemoresistance in HCT116 Colorectal Cancer Cells in Vitro and in vivo. International Journal of Cancer, 129, 476-486. http://dx.doi.org/10.1002/ijc.25670

[51] Harbottle, A., Daly, A.K., Atherton, K. and Campbell, F.C. (2001) Role of Glutathione S-Transferase P1, P-Glycoprotein and Multidrug Resistance-Associated Protein 1 in Acquired Doxorubicin Resistance. International Journal of Cancer (Journal International Du Cancer), 92, 777-783. http://dx.doi.org/10.1002/ijc.1283

[52] Patel, B.B., Sengupta, R., Qazi, S., Vachhani, H., Yu, Y.J., Rishi, A.K. and Majumdar, A.P.N. (2008) Curcumin Enhances the Effects of 5-Fluorouracil and Oxaliplatin in Mediating Growth Inhibition of Colon Cancer Cells by Modulating EGFR and IGF-1R. International Journal of Cancer (Journal International Du Cancer), 122, 267-273. http://dx.doi.org/10.1002/ijc.23097

[53] Liu, H., Zhou, B.H., Qiu, X., Wang, H.S., Zhang, F., Fang, R., et al. (2012) T63, a New 4-Arylidene Curcumin Analogue, Induces Cell Cycle Arrest and Apoptosis through Activation of the Reactive Oxygen Species-FOXO3a Pathway in Lung Cancer Cells. Free Radical Biology and Medicine, 53, 2204-2217. http://dx.doi.org/10.1016/j.freeradbiomed.2012.10.537

[54] Chen, L., Tian, G.Q., Shao, C.X., Cobos, E. and Gao, W.M. (2010) Curcumin Modulates Eukaryotic Initiation Factors in Human Lung Adenocarcinoma Epithelial Cells. Molecular Biology Reports, 37, 3105-3110. http://dx.doi.org/10.1007/s11033-009-9888-5

[55] Xu, Y., Zhang, J.J., Han, J., Pan, X.Y., Cao, Y.J., Guo, H., et al. (2012) Curcumin Inhibits Tumor Proliferation Induced by Neutrophil Elastase through the Upregulation of Alpha1-Antitrypsin in Lung Cancer. Molecular Oncology, 6, 405-417. http://dx.doi.org/10.1016/j.molonc.2012.03.005

[56] Chen, Q.Y., Jiao, D.M., Yao, Q.H., Yan, J., Song, J., Chen, F.Y., Lu, G.H. and Zhou, J.Y. (2012) Expression Analysis of Cdc42 in Lung Cancer and Modulation of Its Expression by Curcumin in Lung Cancer Cell Lines. International Journal of Oncology, 40, 1561-1568.

[57] Bachmeier, B.E., Killian, P., Pfeffer, U. and Nerlich, A.G. (2010) Novel Aspects for the Application of Curcumin in Chemoprevention of Various Cancers. Frontiers in Bioscience (Schol Ed), 2, 697-717. http://dx.doi.org/10.2741/s95

[58] Shehzad, A. and Lee, Y.S. (2010) Curcumin: Multiple Molecular Targets Mediate Multiple Pharmacological Actions: A Review. Drugs of the Future, 35, 113-119. 
[59] Anand, P., Sundaram, C., Jhurani, S., Kunnumakkara, A.B. and Aggarwal, B.B. (2008) Curcumin and Cancer: An “Old-Age” Disease with an “Age-Old” Solution. Cancer Letters, 267, 133-164. http://dx.doi.org/10.1016/j.canlet.2008.03.025

[60] Sun, S.H., Huang, H.C., Huang, C. and Lin, J.K. (2012) Cycle Arrest and Apoptosis in MDA-MB-231/Her2 Cells Induced by Curcumin. European Journal of Pharmacology, 690, 22-30. http://dx.doi.org/10.1016/j.ejphar.2012.05.036

[61] Zhang, H.G., Kim, H., Liu, C., Yu, S., Wang, J., et al. (2007) Curcumin Reverses Breast Tumor Exosomes Mediated Immune Suppression of NK Cell Tumor Cytotoxicity. Biochimica et Biophysica Acta, 1773, 1116-1123. http://dx.doi.org/10.1016/j.bbamcr.2007.04.015

[62] Shishodia, S., Chaturvedi, M.M. and Aggarwal, B.B. (2007) Role of Curcumin in Cancer Therapy. Current Problems in Cancer, 31, 243-305. http://dx.doi.org/10.1016/j.currproblcancer.2007.04.001

[63] Shehzad, A., Khan, S., Shehzad, O. and Lee, Y.S. (2010) Curcumin Therapeutic Promises and Bioavailability in Colorectal Cancer. Drugs of Today, 46, 523-532. http://dx.doi.org/10.1358/dot.2010.46.7.1509560

[64] He, Z.Y., Shi, C.B., Wen, H., Li, F.L., Wang, B.L. and Wang, J. (2011) Upregulation of p53 Expression in Patients with Colorectal Cancer by Administration of Curcumin. Cancer Investigation, 29, 208-213. http://dx.doi.org/10.3109/07357907.2010.550592

[65] Aggarwal, B.B. (2008) Prostate Cancer and Curcumin: Add Spice to Your Life. Cancer Biology \& Therapy, 7, 14361440. http://dx.doi.org/10.4161/cbt.7.9.6659

[66] Dorai, T., Cao, Y.C., Dorai, B., Buttyan, R. and Katz, A.E. (2001) Therapeutic Potential of Curcumin in Human Prostate Cancer. III. Curcumin Inhibits Proliferation, Induces Apoptosis, and Inhibits Angiogenesis of LNCaP Prostate Cancer Cells in vivo. Prostate, 47, 293-303. http://dx.doi.org/10.1002/pros.1074

[67] Mukhopadhyay, A., Bueso-Ramos, C., Chatterjee, D., Pantazis, P. and Aggarwal, B.B. (2001) Curcumin Downregulates Cell Survival Mechanisms in Human Prostate Cancer Cell Lines. Oncogene, 20, 7597-7609. http://dx.doi.org/10.1038/sj.onc.1204997

[68] Sundram, V., Chauhan, S.C., Ebeling, M. and Jaggi, M. (2012) Curcumin Attenuates $\beta$-Catenin Signaling in Prostate Cancer Cells through Activation of Protein Kinase D1. PLoS ONE, 7, e35368. http://dx.doi.org/10.1371/journal.pone.0035368

[69] Lin, Y.G., Kunnumakkara, A.B., Nair, A., Merritt, W.M., Han, L.Y., et al. (2007) Curcumin Inhibits Tumor Growth and Angiogenesis in Ovarian Carcinoma by Targeting the Nuclear Factor- $\kappa B$ Pathway. Clinical Cancer Research, 13, 3423-3430. http://dx.doi.org/10.1158/1078-0432.CCR-06-3072

[70] Watson, J.L., Greenshields, A., Hill, R., Hilchie, A., Lee, P.W., Giacomantonio, C.A. and Hoskin, D.W. (2010) Curcumin-Induced Apoptosis in Ovarian Carcinoma Cells Is p53-Independent and Involves p38 Mitogen-Activated Protein Kinase Activation and Downregulation of Bcl-2 and Survivin Expression and Akt Signaling. Molecular Carcinogenesis, 49, 13-24.

[71] Mukherjee, N., Chakraborty, S., Ghosh, U., Bhattacharyya, N.P., Bhattacharya, R.K., Dey, S. and Roy, M. (2007) Curcumin-Induced Apoptosis in Human Leukemia Cell HL-60 Is Associated with Inhibition of Telomerase Activity. Molecular and Cellular Biochemistry, 297, 31-39. http://dx.doi.org/10.1007/s11010-006-9319-z

[72] Ghosh, A.K., Kay, N.E., Secreto, C.R. and Shanafelt, T.D. (2009) Curcumin Inhibits Prosurvival Pathways in Chronic Lymphocytic Leukemia B Cells and May Overcome Their Stromal Protection in Combination with EGCG. Clinical Cancer Research, 15, 1250-1258. http://dx.doi.org/10.1158/1078-0432.CCR-08-1511

[73] Yang, C.W., Chang, C.L., Lee, H.C., Chi, C.W., Pan, J.P. and Yang, W.C. (2012) Curcumin Induces the Apoptosis of Human Monocytic Leukemia THP-1 Cells via the Activation of JNK/ERK Pathways. BMC Complementary and Alternative Medicine, 12, 22. http://dx.doi.org/10.1186/1472-6882-12-22

[74] Bharti, A.C., Donato, N. and Aggarwal, B.B. (2003) Curcumin (Diferuloylmethane) Inhibits Constitutive and IL-6Inducible STAT3 Phosphorylation in Human Multiple Myeloma Cells. Journal of Immunology, 171, 3863-3871. http://dx.doi.org/10.4049/jimmunol.171.7.3863

[75] Bharti, A.C., Donato, N., Singh, S. and Aggarwal, B.B. (2003) Curcumin (Diferuloylmethane) Down-Regulates the Constitutive Activation of Nuclear Factor- $\kappa \mathrm{B}$ and $\mathrm{I} \kappa \mathrm{B} \alpha$ Kinase in Human Multiple Myeloma Cells, Leading to Suppression of Proliferation and Induction of Apoptosis. Blood, 101, 1053-1062. http://dx.doi.org/10.1182/blood-2002-05-1320

[76] Sung, B., Kunnumakkara, A.B., Sethi, G., Anand, P., Guha, S. and Aggarwal, B.B. (2009) Curcumin Circumvents Chemoresistance in Vitro and Potentiates the Effect of Thalidomide and Bortezomib against Human Multiple Myeloma in Nude Mice Model. Molecular Cancer Therapeutics, 8, 959-970. http://dx.doi.org/10.1158/1535-7163.MCT-08-0905

[77] Vadhan, R.S., Weber, D., Giralt, S., Alexanian, R., Thomas, S., et al. (2007) Curcumin Downregulates NF-кB and Related Genes in Patients with Multiple Myeloma: Results of a Phase I/II Study. Blood (ASH Annual Meeting Abstracts), 110, 1177a. 
[78] Golombick, T., Diamond, T.H., Manoharan, A. and Ramakrishna, R. (2012) Monoclonal Gammopathy of Undetermined Significance, Smoldering Multiple Myeloma, and Curcumin: A Randomized, Double-Blind Placebo-Controlled Cross-Over 4g Study and an Open-Label 8g Extension Study. American Journal of Hematology, 87, 455-460. http://dx.doi.org/10.1002/ajh.23159

[79] Pluen, A., Boucher, Y., Ramanujan, S., Mckee, T.D., Gohongi, T., Di Tomaso, E., Brown, E.B., Izumi, T., Campbell, R.B., Berk, D.A. and Jain, R.K. (2001) Role of Tumor-Host Interactions in Interstitial Diffusion of Macromolecules: Cranial vs. Subcutaneous Tumors. Proceedings of the National Academy of Sciences of the United States of America, 98, 4628-4633. http://dx.doi.org/10.1073/pnas.081626898

[80] Diaconu, C.C., Szathmari, M., Keri, G. and Venetianer, A. (1999) Apoptosis Is Induced in both Drug-Sensitive and Multidrug-Resistant Hepatoma Cells by Soatostatin Analogue RR-232. British Journal of Cancer, 80, 1197-1203.

[81] Cheah, Y.H., Nordin, F.J., Sarip, R., Tee, T.T., Azimahtol, H.L., Sirat, H.M., Rashid, B.A., Adbullah, N.R. and Ismail, Z. (2009) Combined Xanthorrhizol-Curcumin Exhibits Synergistic Growth Inhibitory Activity via Apoptosis Induction in Human Breast Cancer Cells MDA-MB-231. Cancer Cell International, 9, 1. http://dx.doi.org/10.1186/1475-2867-9-1

[82] Siddiqui, I.A., Malik, A., Adhami, V.M., Asim, M., Hafees, B.B., Sarfaraz, S. and Mukhtar, H. (2008) Green Tea Polyphenol EGCG Sensitizes Human Prostate Carcinoma LNCaP Cells to TRAIL-Mediated Apoptosis and Synergistically Inhibits Biomarkers Associated with Angiogenesis and Metastasis. Oncogene, 27, 2055-2063. http://dx.doi.org/10.1038/sj.onc.1210840

[83] Strimpakos, A.S. and Sharma, R.A. (2008) Curcumin: Preventative and Therapeutic Properties in Laboratory Studies and Clinical Trials. Antioxidants \& Redox Signaling, 10, 511-546. http://dx.doi.org/10.1089/ars.2007.1769

[84] PAL, S., Bhattacharyys, S., Choudhuri, T., Datta, G.K., Das, T. and Sa, G. (2005) Amelioration of Immune Cell Number Depletion and Potentiation of Depressed Detoxification System of Tumor-Bearing Mice by Curcumin. Cancer Detection and Prevention, 29, 470-478. http://dx.doi.org/10.1016/j.cdp.2005.05.003

[85] Pal, S., Choudhuri, T., Chattopadjyay, S., Bhattacharya, A., Datta, G.K., Das, T. and Sa, G. (2001) Mechanisms of Curcumin-Induced Apoptosis of Ehrlich’s Ascites Carcinoma Cells. Biochemical and Biophysical Research Communications, 288, 658-665. http://dx.doi.org/10.1006/bbrc.2001.5823

[86] Chakraborty, J., Banerjee, S., Ray, P., Hossain, D.M., Bhattacharyya, S., Adhikary, A., Chattopadhyay, S., Das, T. and Sa, G. (2010) Gain of Cellular Adaptation Due to Prolonged p53 Impairment Leads to Functional Switchover from p53 to p73 during DNA Damage in Acute Myeloid Leukemia Cells. Journal of Biological Chemistry, 285, 33104-33112. http://dx.doi.org/10.1074/jbc.M110.122705

[87] Choudhuri, T., Pal, S., Das, T. and Sa, G. (2005) Curcumin Selectively Induces Apoptosis in Deregulated Cyclin D1 Expressed Cells at G2 Phase of Cell Cycle in p53-Dependent Manner. Journal of Biological Chemistry, 280, 2005920068. http://dx.doi.org/10.1074/jbc.M410670200

[88] Choudhuri, T., Pal, S., Agwarwal, M.L., Das, T. and Sa, G. (2002) Curcumin Induces Apoptosis in Human Breast Cancer Cells through p53-Dependent Bax Induction. FEBS Letters, 512, 334-340. http://dx.doi.org/10.1016/S0014-5793(02)02292-5

[89] Bhattacharyya, S., Mandal, D., Saha, B., Sen, G.S., Das, T. and Sa, G. (2007) Curcumin Prevents Tumor-Induced T Cell Apoptosis through Stat-5a-Mediated Bcl-2 Induction. Journal of Biological Chemistry, 282, 15954-15964. http://dx.doi.org/10.1074/jbc.M608189200

[90] Pal, S., Bhattacharyya, S., Choudhuri, T., Datta, G.K., Das, T. and Sa, G. (2005) Amelioration of Immune Cell Number Depletion and Potentiation of Depressed Detoxification System of Tumor-Bearing Mice by Curcumin. Cancer Detection and Prevention, 29, 470-478. http://dx.doi.org/10.1016/j.cdp.2005.05.003

[91] Bhattacharyya, S., Mandal, D., Sen, G.S., Pal, S., Banerjee, S., Hahiry, L., Finke, J.H., Tannenbaum, C.S., Das, T. and Sa, G. (2007) Tumor-Induced Oxidative Stress Perturbs Nuclear Factor- $\kappa B$ Activity-Augmenting Tumor Necrosis Factor- $\alpha$-Mediated T-Cell Death: Protection by Curcumin. Cancer Research, 67, 362-370. http://dx.doi.org/10.1158/0008-5472.CAN-06-2583

[92] Bhattacharyya, S., Md Sakib Hossain, D., Mahanty, S., Sankar Sen, G., Chattopadhyay, S., Banerjee, S., Chakraborty, J., Das, K., Sarkar, D., Das, T. and Sa, G. (2010) Curcumin Reverses T Cell-Mediated Adaptive Immune Dysfunctions in Tumor Bearing Hosts. Cellular \& Molecular Immunology, 7, 306-315. http://dx.doi.org/10.1038/cmi.2010.11

[93] Sharma, S.K., George, N., Kadhiravan, T., Saha, P.K., Mishra, H.K. and Hanif, M. (2009) Prevalence of Extensively Drug-Resistant Tuberculosis among Patients with Multidrug-Resistant Tuberculosis: A Retrospective Hospital Based Study. Indian Journal of Medical Research, 130, 392-395.

[94] Anuchapreeda, S., Leechanachai, P., Smith, M.M., Amubudkar, S.V. and Limtrakul, P.N. (2002) Modulation of P-Glycoprotein Expression and Function by Curcumin in Multidrug-Resistant Human KB Cells. Biochemical Pharmacology, 64, 573-582. http://dx.doi.org/10.1016/S0006-2952(02)01224-8 
[95] Chearwae, W., Shukla, S., Limtrakul, P. and Ambudkar, S.V. (2006) Modulation of the Function of the Multidrug Resistance-Linked ATP-Binding Cassette Transporter ABCG2 by the Cancer Chemopreventive Agent Curcumin. Molecular Cancer Therapeutics, 5, 1995-2006. http://dx.doi.org/10.1158/1535-7163.MCT-06-0087

[96] Chearwae, W., Wu, C.P., Chu, H.Y., Lee, T.R., Ambudkar, S.V. and Limtrakul, P. (2006) Curcuminoids Purified from Turmeric Powder Modulate the Function of Human Multidrug-Resistance Protein 1 (ABCC1). Cancer Chemotherapy and Pharmacology, 57, 376-388. http://dx.doi.org/10.1007/s00280-005-0052-1

[97] Sharma, M., Manoharlal, R., Shukla, S., Puri, N., Prasad, R., Ambudkar, S.V. and Prasad, R. (2009) Curcumin Modulates Efflux Mediated by Yeast ABC Multidrug Transporter and Is Synergistic with Antifungals. Antimicrobial Agents and Chemotherapy, 53, 3256-3265. http://dx.doi.org/10.1128/AAC.01497-08

[98] Khopde, S.M., Priyadarsini, K.I., Venkatesan, P. and Rao, M.N. (1999) Free Radical Scavenging Ability and Antioxidant Efficiency of Curcumin and Its Substituted Analogue. Biophysical Chemistry, 80, 85-91. http://dx.doi.org/10.1016/S0301-4622(99)00070-8

[99] Kuttan, G., Kumar, K.B., Guruvayoorappan, C. and Kuttan, R. (2007) Antitumor, Anti-Invasion, and Antimetastatic Effects of Curcumin. Advances in Experimental Medicine and Biology, 595, 173-184. http://dx.doi.org/10.1007/978-0-387-46401-5_6

[100] Limtrakul, P., Anuchapreeda, S. and Buddhasukh, D. (2004) Modulation of Human Multidrug-Resistance MDR-1 Gene by Natural Curcuminoids. BMC Cancer, 4, 13. http://dx.doi.org/10.1186/1471-2407-4-13

[101] Wahl, H., Tan, L., Griffith, K., Choi, M. and Liu, J.R. (2007) Curcumin Enhances Apo2L/TRAIL-Induced Apoptosis in Chemoresistant Ovarian Cancer Cells. Gynecologic Oncology, 105, 104-112. http://dx.doi.org/10.1016/j.ygyno.2006.10.050

[102] Deeb, D., Xu, Y.X., Jiang, H., Gao, X., Janakiraman, N., Chapman, R.A. and Gautam, S.C. (2003) Curcumin (Diferuloyl-Methane) Enhances Tumor Necrosis Factor-Related Apoptosis-Inducing Ligand-Induced Apoptosis in LNCaP Prostate Cancer Cells. Molecular Cancer Therapeutics, 2, 95-103.

[103] Deeb, D.D., Jiang, H., Gao, X., Divine, G., Dulchavsky, S.A. and Gautam, S.C. (2005) Chemosensitization of Hormone-Refractory Prostate Cancer Cells by Curcumin to TRAIL-Induced Apoptosis. Journal of Experimental Therapeutics \& Oncology, 5, 81-91.

[104] Deeb, D., Jiang, H., Gao, X., Al-Holou, S., Danylik, A.L., Dulchavsky, S.A. and Gautam, S.C. (2007) Curcumin [1,7-Bis(4-hydroxy-3-methoxyphenyl)-1-6-heptadine-3,5-dione, $\mathrm{C}_{21} \mathrm{H}_{20} \mathrm{O}_{6}$ ] Sensitizes Human Prostate Cancer Cells to Tumor Necrosis Factor-Related Apoptosis-Inducing Ligand/Apo2L-Induced Apoptosis by Suppressing Nuclear Factor- $\kappa \mathrm{B}$ via Inhibition of the Prosurvival Akt Signaling Pathway. Journal of Pharmacology and Experimental Therapeutics, 321, 616-625. http://dx.doi.org/10.1124/jpet.106.117721

[105] Gao, X., Deeb, D., Jiang, H., Liu, Y.B., Dulchavsky, S.A. and Gautam, S.C. (2005) Curcumin Differentially Sensitizes Malignant Glioma Cells to TRAIL/Apo2L-Mediated Apoptosis through Activation of Procaspases and Release of Cytochrome C from Mitochondria. Journal of Experimental Therapeutics and Oncology, 5, 39-48.

[106] Shankar, S., Ganapathy, S., Chen, Q. and Srivastava, R.K. (2008) Curcumin Sensitizes TRAIL-Resistant Xenografts: Molecular Mechanisms of Apoptosis, Metastasis and Angiogenesis. Molecular Cancer, 7, 16. http://dx.doi.org/10.1186/1476-4598-7-16

[107] Jagetia, G.C. and Aggarwal, B.B. (2007) "Spicing Up” of the Immune System by Curcumin. Journal of Clinical Immunology, 27, 19-35. http://dx.doi.org/10.1007/s10875-006-9066-7

[108] Dhandapani, K.M., Mahesh, V.B. and Brann, D.W. (2007) Curcumin Suppresses Growth and Chemoresistance of Human Glioblastoma Cells via AP-1 and NFkB Transcription Factors. Journal of Neurochemistry, 102, 522-538. http://dx.doi.org/10.1111/j.1471-4159.2007.04633.x

[109] Woo, J.H., Kim, Y.H., Choi, Y.J., KIM, D.G., Lee, K.S., Bae, J.H., Min, D.S., Chang, J.S., Jeong, Y.J., Lee, Y.H., Park, J.W. and Kwon, T.K. (2003) Molecular Mechanisms of Curcumin-Induced Cytotoxicity: Induction of Apoptosis through Generation of Reactive Oxygen Species, Down-Regulation of Bcl- $\mathrm{X}_{\mathrm{L}}$ and IAP, the Release of Cycochrome C and Inhibition of Akt. Carcinogenesis, 24, 1199-1208. http://dx.doi.org/10.1093/carcin/bgg082

[110] Goel, A., Kunnumakkara, A.B. and Aggarwal, B.B. (2008) Curcumin as “Curecumin”: From Kitchen to Clinic. Biochemical Pharmacology, 75, 787-809. http://dx.doi.org/10.1016/j.bcp.2007.08.016

[111] Abe, Y., Hashimoto, S. and Horie, T. (1999) Curcumin Inhibition of Inflammatory Cytokine Production by Human Peripheral Blood Monocytes and Alveolar Macrophages. Pharmacological Research, 39, 41-47. http://dx.doi.org/10.1006/phrs.1998.0404

[112] Surh, Y.J., Chun, K.S., Cha, H.H., Han, S.S., Keum, Y.S., Park, K.K. and Lee, S.S. (2001) Molecular Mechanisms Underlying Chemopreventive Activities of Anti-Inflammatory Phytochemicals: Down-Regulation of COX-2 and iNOS through Suppression of NF-Kappa B Activation. Mutation Research, 480-481, 243-268.

[113] Jobin, C., Bradham, C.A., Russo, M.P., Juma, B., Narula, A.S., Brenner, D.A. and Sartor, R.B. (1999) Curcumin 
Blocks Cytokine-Mediated NF-Kappa B Activation and Proinflammatory Gene Expression by Inhibiting Inhibitory Factor I-Kappa B Kinase Activity. Journal of Immunology, 163, 3474-3483.

[114] Huang, M.T., Lysz, T., Ferraro, T., Abidi, T.F., Laskin, J.D. and Conney, A.H. (1991) Inhibitory Effects of Curcumin on in Vitro Lipoxygenase and Cyclooxygenase Activities in Mouse Epidermis. Cancer Research, 51, 813-819.

[115] Bennett, A. (1986) The Production of Prostanoids in Human Cancers, and Their Implications for Tumor Progression. Progress in Lipid Research, 25, 539-542. http://dx.doi.org/10.1016/0163-7827(86)90109-8

[116] Qiao, L., Kozoni, V., Tsioulias, G.J., Koutsos, M.I., Hanif, R., Shiff, S.J. and Rigas, B. (1995) Selected Eicosanoids Increase the Proliferation Rate of Human Colon Carcinoma Cell Lines and Mouse Colonocytes in vivo. Biochimica et Biophysica Acta, 1258, 215-223.

[117] Aggarwal, B.B., Kumar, A. and Bharti, A.C. (2003) Anticancer Potential of Curcumin: Preclinical and Clinical Studies. Anticancer Research, 23, 363-398.

[118] Liu, J.Y., Lin, S.J. and Lin, J.K. (1993) Inhibitory Effects of Curcumin on Protein Kinase C Activity Induced by 12-OTetradecanoyl-Phorbol-13-Acetate in NIH 3T3 Cells. Carcinogenesis, 14, 857-861. http://dx.doi.org/10.1093/carcin/14.5.857

[119] Cho, J.W., Lee, K.S. and Kim, C.W. (2007) Curcumin Attenuates the Expression of IL-L $\beta$, IL-6, and TNF- $\alpha$ as Well as Cyclin E in TNF- $\alpha$-Created HaCaT Cells: NF- $\mathrm{kB}$ and MAPKs as Potential Upstream Targets. International Journal of Molecular Medicine, 19, 469-474.

[120] Soudamini, K.K., Unnikrishnan, M.C., Soni, K.B. and Kuttan, R. (1992) Inhibition of Lipid Peroxidation and Cholesterol Levels in Mice by Curcumin. Indian Journal of Physiology and Pharmacology, 36, 239-243.

[121] Reddy, A.C.P. and Lokesh, B.R. (1994) Dietary Unsaturated Fatty Acids, Vitamin E, Curcumin and Eugenol Alter Serum and Liver Lipid Peroxidation in Rats. Nutrition Research, 14, 1423-1437. http://dx.doi.org/10.1016/S0271-5317(05)80301-X

[122] Reddy, A.C.P. and Lokesh, B.R. (1994) Alterations in Lipid Peroxides in Rat Liver by Dietary n-3 Fatty Acids: Modulation of Antioxidant Enzymes by Curcumin, Eugenol, and Vitamin E. Journal of Nutritional Biochemistry, 5, 181-188. http://dx.doi.org/10.1016/0955-2863(94)90070-1

[123] Rukkumani, R., Aruna, K., Varma, P.S., Rajasekaran, K.N. and Menon, V.P. (2004) Comparative Effects of Curcumin and an Analog of Curcumin on Alcohol and PUFA Induced Oxidative Stress. Journal of Pharmacy and Pharmaceutical Sciences, 7, 274-283.

[124] Suryanarayana, P., Saraswat, M., Mrudula, T., Krishna, T.P., Krishnaswamy, K. and Reddy, G.B. (2005) Curcumin and Turmeric Delay Streptozotocin Induced Diabetic Cataract in Rats. Investigative Ophthalmology \& Visual Science, 46, 2092-2099. http://dx.doi.org/10.1167/iovs.04-1304

[125] Thresiamma, K.C., George, J. and Kuttan, R. (1996) Protective Effect of Curcumin, Ellagic Acid and Bixin on Radiation Induced Toxicity. Indian Journal of Experimental Biology, 34, 845-847.

[126] Lawhavinit, O.A., Kongkathip, N. and Kongkathip, B. (2010) Antimicrobial Activity of Curcuminoids from Curcuma longa L. on Pathogenic Bacteria of Shrimp and Chicken. Kasetsart Journal —Natural Science, 44, 364-371.

[127] Mun, S.H., Joung, D.K., Kim, Y.S., et al. (2013) Synergistic Antibacterial Effect of Curcumin against Methicillin-Resistant Staphylococcus aureus. Phytotherapy Research, 19, 599-604.

[128] Rai, D., Singh, J.K., Roy, N. and Panda, D. (2008) Curcumin Inhibits FtsZ Assembly: An Attractive Mechanism for Its Antibacterial Activity. Biochemical Journal, 410, 147-155. http://dx.doi.org/10.1042/BJ20070891

[129] Kaur, S., Modi, N.H., Panda, D. and Roy, N. (2010) Probing the Binding Site of Curcumin in Escherichia coli and Bacillus subtilis FtsZ-A Structural Insight to Unveil Antibacterial Activity of Curcumin. European Journal of Medicinal Chemistry, 45, 4209-4214. http://dx.doi.org/10.1016/j.ejmech.2010.06.015

[130] Li, C.J., Zhang, L.J., Dezube, B.J., Crumpacker, C.S. and Pardee, A.B. (1993) Three Inhibitors of Type 1 Human Immunodeficiency Virus Long Terminal Repeat-Directed Gene Expression and Virus Replication. Proceedings of the National Academy of Sciences of the United States of America, 90, 1839-1842. http://dx.doi.org/10.1073/pnas.90.5.1839

[131] Chen, D.Y., Shien, J.H., Tiley, L., Chiou, S.S., Wang, S.Y., Chang, T.J., et al. (2010) Curcumin Inhibits Influenza Virus Infection and Haemagglutination Activity. Food Chemistry, 119, 1346-1351. http://dx.doi.org/10.1016/j.foodchem.2009.09.011

[132] Zandi, K., Ramedani, E., Mohammadi, K., Tajbakhsh, S., Deilami, I., Rastian, Z., et al. (2010) Evaluation of Antiviral Activities of Curcumin Derivatives against HSV-1 in Vero Cell Line. Natural Product Communications, 5, 1935-1938.

[133] Kutluay, S.B., Doroghazi, J., Roemer, M.E. and Triezenberg, S.J. (2008) Curcumin Inhibits Herpes Simplex Virus Immediate-Early Gene Expression by a Mechanism Independent of p300/CBP Histone Acetyltransferase Activity. Virology, 373, 239-247. http://dx.doi.org/10.1016/j.virol.2007.11.028 
[134] Divya, C.S. and Pillai, M.R. (2006) Antitumor Action of Curcumin in Human Papillomavirus Associated Cells Involves Downregulation of Viral Oncogenes, Prevention of NFkB and AP-1 Translocation, and Modulation of Apoptosis. Molecular Carcinogenesis, 45, 320-332. http://dx.doi.org/10.1002/mc.20170

[135] Prusty, B.K. and Das, B.C. (2005) Constitutive Activation of Transcription Factor AP-1 in Cervical Cancer and Suppression of Human Papillomavirus (HPV) Transcription and AP-1 Activity in HeLa Cells by Curcumin. International Journal of Cancer, 113, 951-960. http://dx.doi.org/10.1002/ijc.20668

[136] Dutta, K., Ghosh, D. and Basu, A. (2009) Curcumin Protects Neuronal Cells from Japanese Encephalitis Virus-Mediated Cell Death and also Inhibits Infective Viral Particle Formation by Dysregulation of Ubiquitin-Proteasome System. Journal of Neuroimmune Pharmacology, 4, 328-337. http://dx.doi.org/10.1007/s11481-009-9158-2

[137] Upendra, R.S., Khandelwal, P. and Reddy, A.H.M. (2011) Turmeric Powder (Curcuma longa Linn.) as an Antifungal Agent in Plant Tissue Culture Studies. International Journal of Engineering Science and Technology, 3, 7899-7904.

[138] Wu, J.H. and Wen, H. (2009) Antifungal Susceptibility Analysis of Berberine, Baicalin, Eugenol and Curcumin on Candida albicans. Journal of Medical Colleges of PLA, 24, 142-147. http://dx.doi.org/10.1016/S1000-1948(09)60030-7

[139] Neelofar, K., Shreaz, S., Rimple, B., Muralidhar, S., Nikhat, M. and Khan, L.A. (2011) Curcumin as a Promising Anticandidal of Clinical Interest. Canadian Journal of Microbiology, 57, 204-210. http://dx.doi.org/10.1139/W10-117

[140] Khan, N., Shreaz, S., Bhatia, R., Ahmad, S.I., Muralidhar, S., Manzoor, N. and Khan, L.A. (2012) Anticandidal Activity of Curcumin and Methyl Cinnamaldehyde. Fitoterapia, 83, 434-440. http://dx.doi.org/10.1016/j.fitote.2011.12.003

[141] Sharma, M., Manoharlal, R., Puri, N. and Prasad, R. (2010) Antifungal Curcumin Induces Reactive Oxygen Species and Triggers an Early Apoptosis but Prevents Hyphae Development by Targeting the Global Repressor TUP1 in Candida albicans. Bioscience Reports, 30, 391-404. http://dx.doi.org/10.1042/BSR20090151

[142] Sharma, M., Manoharlal, R., Negi, A.S. and Prasad, R. (2010) Synergistic Anticandidal Activity of Pure Polyphenol Curcumin I in Combination with Azoles and Polyenes Generates Reactive Oxygen Species Leading to Apoptosis. FEMS Yeast Research, 10, 570-578.

[143] Tsao, S.M. and Yin, M.C. (2000) Enhanced Inhibitory Effect from Interaction of Curcumin with Amphotericin B or Fluconazole against Candida Species. Journal of Food and Drug Analysis, 8, 208-212.

[144] Menuel, S., Joly, J.P., Courcot, B., Elysée, J., Ghermani, N.E. and Marsura, A. (2007) Synthesis and Inclusion Ability of a Bis- $\beta$-Cyclodextrin Pseudo-Cryptand towards Busulfan Anticancer Agent. Tetrahedron, 63, 1706-1714. http://dx.doi.org/10.1016/j.tet.2006.10.070

[145] Davis, M.E. and Brewster, M.E. (2004) Cyclodextrin-Based Pharmaceutics: Past, Present and Future. Nature Reviews Drug Discovery, 3, 1023-1035. http://dx.doi.org/10.1038/nrd1576

[146] Tonnesen, H.H., Másson, M. and Loftsson, T. (2002) Studies of Curcumin and Curcuminoids. XXVII. Cyclodextrin Complexation: Solubility, Chemical and Photochemical Stability. International Journal of Pharmaceutics, 244, 127135. http://dx.doi.org/10.1016/S0378-5173(02)00323-X

[147] Aqil, F., Munagala, R., Jeyabalan, J. and Vadhanam, M.V. (2013) Bioavailability of Phytochemicals and Its Enhancement by Drug Delivery Systems. Cancer Letters, 334, 133-141. http://dx.doi.org/10.1016/j.canlet.2013.02.032

[148] 1Yallapu, M.M., Jaggi, M. and Chauhan, S.C. (2010) $\beta$-Cyclodextrin-Curcumin Self-Assembly Enhances Curcumin Delivery in Prostate Cancer Cells. Colloids and Surfaces B: Biointerfaces, 79, 113-125. http://dx.doi.org/10.1016/j.colsurfb.2010.03.039

[149] Yadav, V.R., Prasad, S., Kannappan, R., Ravindran, J., Chaturvedi, M.M., Vaahtera, L., et al. (2010) CyclodextrinComplexed Curcumin Exhibits Anti-Inflammatory and Antiproliferative Activities Superior to Those of Curcumin through Higher Cellular Uptake. Biochemical Pharmacology, 80, 1021-1032. 